\title{
Vegetable vs meat ingestion: The effects on barpressing
}

\author{
LAWRENCE WEINSTEIN \\ University of New Brunswick, Saint John, New Brunswick, Canada
}

Two groups of $30 \mathrm{Wistar}$ rats each ate 20 calories of vegetables or 20 calories of meat in a barpressing situation with saccharine as reward. The vegetable-eating animals performed at a higher level than the meat-eating animals. The results are consonant with recent investigations which have demonstrated vegetarian vs meatarian differences in university examination performance and the general area of emotional upset. The present barpress data and the above university performance and emotionality effects with differences in eating regimes are at the least encouraging of further research in this area of nutritional psychology.

Popular belief contends that relatively strict vegetarians behave differently from those who eat meat. No study has examined the effects of such dietary regimes on barpressing (when total dietary caloric intake is equated across the two food types), a typically used operant response. To gather information relevant to such popular belief of differences in behavior due to differences in meat or vegetable diets, the present investigation examined barpressing by rats maintained under two different types of food regimes: (1) vegetables and (2) meat.

\section{METHOD}

\section{Subjects}

The subjects were 60 experimentally naive male albino Wistar rats, 100 to $150 \mathrm{~g}$ in weight, 30 to 40 days of age at the start of the experiment, housed in individual cages.

\section{Ápparatus}

Dixie cups which served as foodcups were mounted on the inside of 60 experimental cages. The operant chamber has been described previously (Weinstein, 1970).

\section{Procedure}

Directly after weaning, 30 subjects were randomly assigned to each of the two conditions: vegetable (V) or meat $(M)$. The former group received $56 \mathrm{~g}$ of uncooked finely chopped carrots; the $\mathrm{M}$ group received $14 \mathrm{~g}$ of raw, ground, lean, round steak. Each group received 20 calories in the above fashion for part or all of $1 \mathrm{~h}$ (training hour) and $23 \mathrm{~h}$ of food deprivation, for 100 days. That is, all vegetable or meat animals ingested their respective foods within the 1 training hour. The operant sessions lasted for 25 days and began on the 101 st postweaning day. Each conditioned reinforcement session was 40 reinforcements (dipper presentations) in length. The reward for both groups was a $.10 \%$ saccharine solution (no caloric value). After each operant session, the vegetable animals received their 20 calories $(56 \mathrm{~g}$ of carrots) and the meat subjects ingested their 20 calories $(14 \mathrm{~g}$ of meat). Thus, on each of the 100 postweaning days, and after each of the 25 operant sessions, 30 animals ate 20 calories in meat and 30 animals ingested 20 calories in vegetables.

Requests for reprints should be sent to Dr. L. Weinstein, Assistant Professor of Psychology, University of New Brunswick, Saint John, New Brunswick E2L 4L5, Canada.

\section{RESULTS}

The mean body weights of the two groups for the initial 100 days and subsequent 25 days were not significantly different by an analysis of variance $[F(1,58)=1.61, p>.05]$. Figure 1 indicates that, from Sessions 15 to $25, \mathrm{~V}$ performed at a higher level than $\mathrm{M}$. The mean number of barpresses between $\mathrm{V}$ and $\mathrm{M}$ for Sessions 15 to 25 indicated statistical significance by an analysis of variance $[\mathrm{F}(1,58)=8.01, \mathrm{p}<.025]$.

\section{DISCUSSION}

It seems that, at least in a barpressing situation, vegetables produce higher levels of behavior than when meat is the alternative, and all types of caloric intake are equated. While one is tempted to leave these results with the laboratory barpress response above, other very recent data support the notion that vegetarian diets do in fact produce differences from meat-

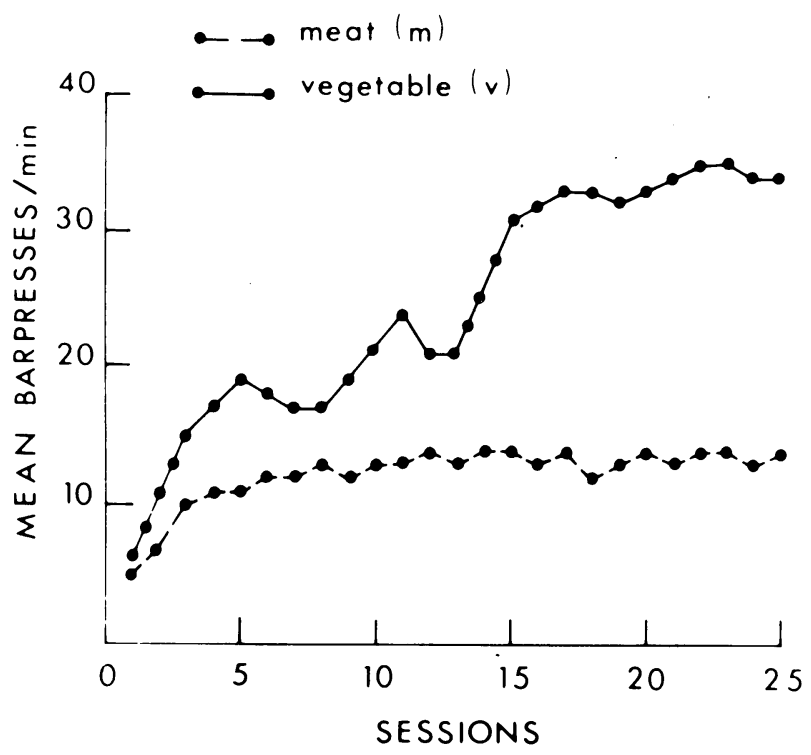

Figure 1. Mean barpresses per minute as a function of type of diet. 
eating regimes in university examination performance, with vegetarians scoring higher than meatarians (Weinstein \& Staubi, 1977), and in the general area of emotionality. Weinstein (in press) has most lately demonstrated that vegetable breakfasts produce less frustration and generally lower levels of irascibility than do meat breakfasts.

Further investigations are underway in the present labboratories to determine the extent of such vegetable vs meat differences on motor behavior other than barpressing, such as runway performance. At the present, it appears that there is support for the notion that vegetarians respond (in a variety of ways) different from meatarians.

\section{REFERENCES}

Weinstein, L. Negative incentive contrast effects with saccharine versus sucrose and partial reinforcement. Psychonomic Science, 1970, 21, 276-278.

WeINSTEIN, L. Vegetarianism vs meatarianism and emotional upset. Bulletin of the Psychonomic Society, in press.

Weinstein, L., \& Staubi, W. H. W. Vegetables make you more successful at university than meat. IRCS Medical Science, 1977, 5, 14.

(Received for publication January 29, 1977.) 